\title{
Policy For Strengthening Village Local Institutions Traditions In The Use Of Space In Tourism Area In The Province Of Bali
}

\author{
Ni Ketut Sari Adnyani ${ }^{1}$, Komang Febrinayanti Dantes ${ }^{1}$ \\ niktsariadnyani@gmail.com, febrinayanti.dantes@undiksha.ac.id \\ ${ }^{1}$ Universitas Pendidikan Ganesha, Indonesia
}

\begin{abstract}
The purpose of this research is to determine the control arrangements for spatial use in tourism areas in Bali Province by strengthening local traditional village institutions; to find out the construction of policies for strengthening local traditional village institutions in the use of space in the tourism area in Bali Province in realizing the welfare of traditional village manners in Bali. This research is a normative legal research with a sociolegal approach. This research approach uses a statutory approach, a conceptual approach, and a case approach that examines a legal approach with a policy orientation. From the analysis of the research results, it can be analyzed that the normative problem of empty norms or norms and the formulation of ideal norms of regulating traditional village recognition in sustainable tourism development by considering the concept of sustainable tourism development, considering the philosophical aspects of justice and welfare of traditional villages by considering economic, political aspects , social, cultural, religious, and human rights. The Regional Long-Term Development Plan (RPJPD) of the Province of Bali for 2005-2025, namely Bali Dwipa Jaya Based on Tri Hita Karana. To Traditional Villages with a management system, maintenance under the autonomy authority of Traditional Villages in a condition that still gives portions to Traditional Villages.
\end{abstract}

Keywords: traditional village, institutional, local, RTRWP.

\section{Introduction}

The coastal areas and small islands of Bali Province are experiencing development rapid development, both directly and indirectly rely on on coastal resources and small islands. Coastal areas and small islands have developed into centers of economic growth. Different from In other areas, the development of Bali Province relies on the tourism sector as a leading and multiplier sector that has close links in encouraging other sectors such as fisheries, transportation, manufacturing and other services. The contribution of the tourism sector through the provision of accommodation and food/drink for value creation added the economy of Bali Province.

The Bali government is trying to restore Bali tourism, one of which is through efforts to implement Clean, Health, Security, and Environment (CHSE) certification for tourism businesses in Bali. To support the implementation of this CHSE certification, the Bali Regional Government since 2 June 2020 has formed a Protocol Verification Team for the New Era of Life Order in the Tourism Sector. As of early November 2020, there have been 745 CHSE-certified tourism 
businesses, including hotels, restaurants and tourist attractions. It can be seen in graph 1 and graph 2, below.

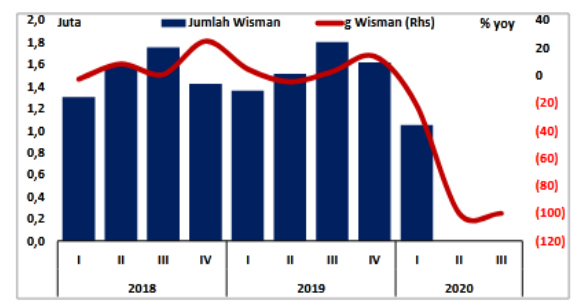

Fig. 1. Average Length of Stay in Star and Non-Star Hotels Source: BPS Bali Province, processed

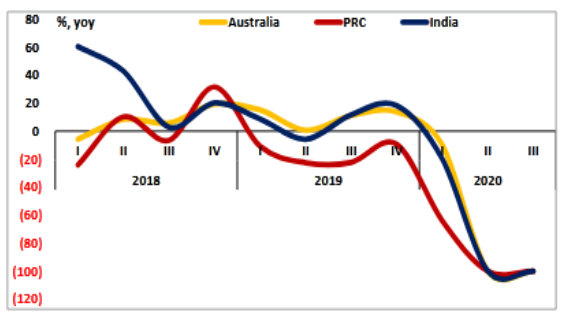

Fig. 2. Visits of Foreign Tourists to Bali Quarterly

Source: BPS Provinsi Bali, diolah

Based on the data graph above, it shows that tourist visits, especially wisdom, are expected to improve in the fourth quarter of 2020 in line with the Christmas and New Year holidays. Improvements in the transportation business field are also driven by the resumption of demand for goods from trading partner countries. ${ }^{1}$ The tourism sector, utilization of natural resources and environmental services for coastal and small islands are also likely to be growing rapidly in line with the development of national tourism development which experienced positive growth. The growth of the national tourism market, especially the Asian and Pacific markets, is likely to continue to grow in the future in line with advances in information technology and transportation [1].

The rapid development in WP3K on the one hand has contributed greatly to the improvement of the regional economy, but on the other hand various problems have emerged. Complex problems include damage and alteration of coastal ecosystems, coastal erosion/abrasion, pollution of coastal waters, reduced turtle nesting habitat, decline in fish resources and conflicts over the use of coastal resources and small islands. ${ }^{2}$ 
The various problems above are the impact of the development of coastal areas and small islands that tend to be transformative which changes the landscape and are exploitative. to the coastal ecosystem. Coastal areas and small islands are also still pockets of poverty in Bali, especially the coastal areas outside Denpasar City, Badung and Gianyar Regencies. Meanwhile, optimizing the utilization of the potential of coastal water resources through increased investment in order to expand employment and business opportunities is still hampered by the void of regulation on the use of marine space.

The Tri Hita Karana philosophy in Bali is very relevant to be used as a reference in the control and use of space in the Wewidangan krama of the traditional village as a form of strengthening the institution of Traditional Villages in the Province of Bali. This contains the essence that the use of space is based on elements of the value of the balance of relations between humans and God, between humans and others, and between humans and their environment. In Bali, there are several local wisdoms that are used as a reference in controlling the use of space, such as: "upstream-teben", namely upstream is the head or main and teben is downstream or disgraceful. The concept of Hulu-teben is used in determining the direction, place, layout in making a house or holy place. In addition, "Tri Mandala" is also one of the local wisdoms which is a pattern of dividing the territory, area and/or yard which is divided into three levels consisting of: main mandala, middle mandala and nista mandala.

The local wisdom system for strengthening traditional village institutions is reflected in local knowledge and technology systems in various regions, which are still predominantly colored by customary values, as can be seen from the ways in which these traditional institutions strengthen the principles of conservation, management and exploitation of space use. The long process carried out by adat village krama in the context of strengthening traditional village institutions in interacting and adapting to their environment gives birth to the ability to develop ways to sustain life through value systems, lifestyles, institutional systems that are adapted to their environment. ${ }^{3}$ In other words, local wisdom built from strengthening traditional village institutions is a manifestation of the implementation of articulation and embodiment of traditional forms of knowledge that are understood by humans or the manners of traditional villages that interact with the surrounding nature, including the use of space in tourism areas. The phenomenon of spatial planning violations in tourism areas in Bali is caused by the increasing need for land for tourism facilities and infrastructure. The economic value of land financially causes land owners to give up their land to be sold to investors [2], [3].

Development of tourism facilities and infrastructure targeting rice fields that are still productive so that land conversion is difficult to control. The high rate of land conversion in tourism areas in Bali indirectly threatens the existence of subak. In Article 1 point 4, Bali Provincial Regulation Number 9 of 2012 concerning Subak, it is explained that subak is a traditional organization in the field of water use and or plant management at the farm level for indigenous peoples in Bali that are socio-agricultural, religious, and religiously economical. and historically continues to grow which has a very high philosophical value. The development of agricultural development specifically for food crops in Bali cannot be separated from the existence 
of subak which has been formed long ago as a socio-agrarian religious community which is local wisdom.

Referring to the provisions of Article 32 paragraph (2) of the UUPR, it is determined that the provision of incentives is a tool or effort to provide rewards for the implementation of activities that are in line with the spatial plan. The incentives can be in the form of (a) tax relief; granting concessions; cross subsidies; rewards; space rent; and crowdfunding; (b) infrastructure development and procurement; (c) ease of licensing procedures; (d) awarding awards to the public, private sector and/or local government. Further provisions regarding the implementation of spatial planning are regulated through Government Regulation Number 15 of 2010 concerning the Implementation of Spatial Planning (hereinafter referred to as PP on the Implementation of Spatial Planning). In Article 175, determining the mechanism or procedure for providing incentives is given authority to the Regional Government.

In the field of spatial planning, the Bali Provincial Government has issued Bali Provincial Regulation Number 16 of 2009 concerning the 2009-2029 Provincial Spatial Planning (RTRWP) (hereinafter referred to as the Bali RTRW Perda) ${ }^{4}$. Article 42 of the Regional Regulation stipulates the existence of a protected area which includes a local protected area. The definition of a protected area is stated in Article 1 number 26 which defines a protected area as "an area designated with the main function of protecting environmental sustainability which includes a local protected area. The definition of a protected area is stated in Article 1 number 26 which defines a protected area as "an area designated with the main function of protecting environmental sustainability which includes natural resources and artificial resources." The scope of this local protected area includes areas of holy places, borders (beaches, rivers, lakes, ravines) and green open spaces (Article 44) [4].

Within the protected area (local protection), some of which include areas in the form of parcels of land with property rights status. With the stipulation of the land as a protected area, the land owner cannot freely use his land according to his own interests. The zoning of protected areas for proprietary lands contradicts the essence of property rights over the land itself. Based on Article 20 of the LoGA, property rights are rights to land. Thus, the owner of the property right should be able to use his land for any purpose, including constructing buildings on it.Based on the formal procedural provisions, this is where the problem lies because the karma of the customary village feels that it does not get justice so that it fights by violating the determination of the protected area. Where the person concerned feels that he does not get concessions from the Government. On the other hand, the Bali RTRW Regional Regulation has not regulated the procedure for providing incentives for lands located in protected areas (local protection).Referring to the above background, it is important to conduct an in-depth, comprehensive and critical study of the strengthening of local traditional village institutions in the use of space in tourism areas in Bali Province in realizing sustainable development with an environmental perspective in a comprehensive manner, by paying attention to economic factors and the interests of regional spatial planning. which has implications for the welfare of traditional village manners in Bali. Through this research, the policy for the management of the Coastal Zone and Small Islands 
(WP3K) is an action taken as the basis for achieving the management objectives of the WP3K so as to create an orderly, safe, productive and sustainable spatial allocation order.

\section{Method}

This research is a normative legal research with a sociolegal approach. This research approach uses a statutory approach, a conceptual approach, and a case approach that examines a legal approach with a policy orientation. From the analysis of the research results, it can be analyzed that the normative problem of norms or empty norms and the formulation of ideal norms for regulating the recognition of customary villages in sustainable tourism development by considering the concept of sustainable tourism development, taking into account the philosophical aspects of justice and welfare of traditional villages by considering economic, political, social, culture, religion and human rights.

The method is implemented through desk study. The first step is to carry out a literature study as a starting point or reference for the formulation of WP3K management policies in Bali Province. Literature study was conducted to collect initial secondary data. Furthermore, secondary data collection was also carried out through FGDs. Focus Group Discussion (FGD)/Thematic Discussion aims to collect secondary data from relevant agencies and stakeholders such as government agencies, the business world, academics, and representatives public. Descriptive data generated in the research, either in the form of oral data, written data, or documents from competent sources and informants (keys and experts) will be collected using qualitative exploratory research techniques and methods. The sampling technique used was purposive sampling technique. The researcher as an instrument goes directly to the field with involved or participatory observations to make observations, recordings, and taking photo documentation, sound recordings and so on during significant processes. This qualitative descriptive analysis technique is carried out to obtain data in the form of detailed descriptive information. about the meaning of an object, action, interaction and related events in people's lives. In this case, the researcher explores the subject side, from the mindset, attitudes and praxis in cultural actions as well as local community economic actions in the dynamics of development in the coastal area of Bali Province.

\section{Result and Discussion}

Regulation of Spatial Utilization Control in Tourism Areas in Bali Province by Strengthening Traditional Village Institutions

According to the Bali Provincial Regulation Number 4 of $2019^{5}$ concerning Traditional Villages, the Traditional Village is a unit of the Customary Law community in the Province of Bali which has a unity of tradition and tradition. The manners of social life of the Hindu community are passed down from generation to generation in the ties of Kahyangan Tiga or Kahyangan Desa which have certain areas and their own assets and are entitled to take care of their own household. Each Traditional Village has its own rules called Awig-awig Traditional Village [5], [6]. In general, Traditional Villages have an identity, existence, role and obligations 
that are built on the basis of the Tri Hita Karana concept, ${ }^{6}$ namely the Parahyangan element (attachment to the same place of worship), the Pawongan element (attachment to fellow citizens or manners). customs, especially those who are Hindu), and elements of Palemahan (attachment to the territorial area).

The urgency of the research, namely, spatial planning requires the existence of an RTRWP as the spatial dimension of the Bali Province RPJPD, which is expected to be able to realize a dynamic spatial unit and can anticipate the demands of development developments that lead to environmental conservation efforts in accordance with the Tri Hita Karana philosophy. Tri Hita Karana is based on the value elements of the balance of the relationship between humans and God, between humans and humans, and between humans and their environment.

The number of Pakraman Villages in Bali Province in 2021 is 1,493 units with details by district/city ranging from 35-344 units. Traditional villages in coastal areas and small islands amounted to 772 units or $51.74 \%$. Considering that the entire area of the Bali Province is a Traditional Village area, the entire Bali Province WP3K is also a unit customary law community. Besides the Traditional Village, the Customary Law community in particular in WP3K whose existence is recognized is Bendega based on the Bali Provincial Regulation No. 11 of 2021 concerning Bendega. According to this regulation, Bendega is a traditional institution in the field of marine and fisheries for indigenous peoples in Bali who are in coastal areas, are economic, social, cultural and religious in nature which historically continues to grow and develop in accordance with the provisions of this regulation. with Balinese culture and local wisdom.

Bendega is concretely spread in fishing centers throughout Bali. Each Bendega Institution has Palemahan, Pawongan and Parhyangan. Palemahan can be physically tangible in the form of a boat base location/place on the coast and the surrounding sea. Pawongan can be manifested in the form of krama (community members) marine and fisheries or such as fishermen). While Parhyangan is in the form of Pura Segara (Swagina Temple to worship God in his manifestation as the Lord of the Sea). Based on the regulation above, all fishing bases throughout Bali that meet 3 requirements, namely the existence of Palemahan (Space), Pawongan (Citizens/Members) and Parhyangan (Pura Segara) are customary law community units recognized by the state [7].

Policy Construction of Institutional Strengthening of Local Traditional Villages in Utilization of Space in Tourism Areas in Bali Province in Realizing Welfare

In Bali, there are 1,493 (one thousand four hundred and ninety three) Traditional Villages that have been confirmed, with a distribution per district/city according to the following details: Buleleng 17, Jembrana 64, Bangli 168, Badung 122, Gianyar 273, Tabanan 349, Karangasem 190 , Klungkung 122, and Denpasar 35.

There are 3 (three) basic considerations for regulating the recognition and inauguration of Traditional Villages in Bali in Perda Bali 4/2019, both philosophical, sociological and juridical considerations. ${ }^{7}$ Based on the Tri Hita Karana philosophy, the Traditional Village as a territorial KMHA is rooted in the local wisdom of Sad Kerthi and is inspired by Hindu religious teachings and cultural values as well as local wisdom that lives in Bali. ${ }^{8}$ protection, guidance, development 
and empowerment in the context of realizing the life of Balinese manners which is politically sovereign, economically independent.

Bali is a unitary space, including land, sea and air space, with a land area of approximately $559,472.91 \mathrm{Ha}$, is a small island ecosystem unit, and is part of a large spatial unit, namely the territorial space of the Republic of Indonesia. In the national context, Bali is a small island that does not have abundant natural resources, but has a comparative advantage in terms of cultural uniqueness and natural beauty, which are the basic capital for Bali in carrying out regional development. The uniqueness of culture and nature has placed Bali as one of the leading tourist destinations in Indonesia and the world and has been declared the most beautiful island in the world.

The rapid development of Bali tourism has contributed in the form of job creation and investment, which on the other hand has resulted in high migration to the island of Bali, especially in the southern Bali region, both from the Bali region and outside the Bali region. The development of tourism which has resulted in various advances in various fields of life, on the other hand has also caused various development problems, which have direct implications for the carrying capacity of space, such as: increasing demand for land, both for settlements and for tourism activities; increased and rapid conversion of agricultural land functions; reduced area vegetation cover; increased traffic concentration resulting in traffic jams; increasing number of critical lands; decreasing level of regional facilities and infrastructure services; social problems of population and employment; as well as the waning of cultural values as a marker of the identity of the people and region of Bali.

These problems, which are also spatial planning issues, are a serious challenge for the Bali region, especially related to efforts to achieve the Bali development vision as stated in the Bali Province Long Term Development Plan (RPJPD) 2005-2025, namely Bali Dwipa Jaya. Based on Tri Hita Karana. The Vision and Mission of the Governor and Deputy Governor of Bali for 20182023, namely "Nangun Sat Kerthi Loka Bali" through the Planned Universe Development Pattern, further strengthens the long-term vision of the development of the Province of Bali. Tri Hita Karana is based on the value elements of the balance of the relationship between humans and God, between humans and humans, and between humans and their environment. The application of the elements of each of these philosophies is explained as follows [8]:

1. Elements of the value of balance and harmony in the relationship between humans and God, reflected in the form of efforts to protect holy places and sacred areas which are believed to have sacred values, as a place for humans to connect themselves with God, which is further included in the RTRWP These areas will be designated as areas that must be protected, both within protected areas and cultivated areas.

2. Elements of the value of balance and harmony in the relationship between humans and humans are reflected in the form of efforts to organize and manage residential areas as a place or space for humans to carry out social interactions in a safe, peaceful and civilized manner, as well as being able to guarantee the optimal development of human resources to improve welfare and fulfillment.

3. Elements of the value of balance and harmony in the relationship between humans and the natural environment are reflected in the efforts to organize and manage natural resources so that they can be used sustainably, both for the benefit of the present and future Balinese generations. 
Nangun Sat Kerthi Loka Bali is a planned universal development pattern which implies maintaining the sanctity and harmony of Bali's nature and its contents, to realize a prosperous and happy Balinese manners life, sakala-niskala towards the life of Balinese manners and gumi in accordance with Bung Karno's Trisakti principle: sovereign sovereignty political, economically independent, and have a personality in culture through development in a patterned, comprehensive, planned, directed, and integrated manner within the framework of the Unitary State of the Republic of Indonesia [9].

Overcoming problems and realizing the long-term and medium-term vision and mission of the Province of Bali requires preventive efforts so as not to cause negative impacts on environmental conservation efforts, both physical and socio-cultural. ${ }^{9}$ One of the efforts that must be taken is to carry out spatial planning activities that include the process of spatial planning, space utilization, and controlling space utilization. In the early stages of the spatial planning process, it is necessary to have a Provincial Spatial Planning (RTRWP) as the spatial dimension of the Provincial RPJPD, and the direction of the Provincial RPJMD which is expected to be able to realize a dynamic spatial unit and can anticipate the demands of development developments that lead to efforts environmental preservation in accordance with the philosophy of Tri Hita Karana and Nangun Sat Kerthi Loka Bali. [10] The Bali Province WP3K management policies are as follows:

1. Development and consolidation of conservation areas in coastal areas and small islands as a priority for the allocation of marine space as a manifestation of -based management ecosystem;

2. Mainstreaming social, cultural, spiritual values, and local wisdom in WP3K management;

3. Prevention, control, recovery and rehabilitation of coastal resources and small islands in an integrated manner;

4. Improving disaster mitigation and climate change adaptation;

5. Optimizing the use of coastal resources and small islands based on an integrated area by strengthening community empowerment and encouraging government, public and private investment equally between regions;

6. Development of an integrated WP3K management system and approach;

7. Improved accessibility and support for infrastructure and facilities in the management of WP3K.

The implication of the policy reconstruction is that each province is required to have a Zoning Plan for Coastal Zone and Small Islands based on Law of the Republic of Indonesia No.23 of 201 ${ }^{10}$ concerning Regional Government Article 14. Document of Zoning Plan for Coastal Zone and Small Islands for a province requires a description of the potential of coastal resources and small islands and their utilization activities, regional strategic issues, objectives, policies and strategies for managing coastal areas and small islands, space allocation plans, spatial utilization regulations and program indications. 


\section{Conclusion}

The implementation of spatial planning in Indonesia has been regulated by Law Number 26 of 2007 concerning Spatial Planning. There is a Government Regulation Number 68 of 2010 concerning Forms and Procedures for the Role of the Community in Spatial Planning and a Regional Regulation of the Province of Bali Number 16 of 2009 concerning the RTRW of Bali. Spatial planning with an environmental perspective needs to pay attention to 2 (two) important dimensions, namely: 1) regional scale, and 2) community scale. The basis for consideration of setting the recognition and inauguration of Traditional Villages in Bali in the Bali Regional Regulation 4/2019 concerning Traditional Villages. The rapid development of Bali tourism has contributed in the form of job creation and investment. Spatial planning issues are a serious challenge for the Bali region, especially related to efforts to achieve the Bali development vision as stated in the 2005-2025 Regional Long Term Development Plan (RPJPD), namely Bali Dwipa Jaya Based on Tri Hita Karana. Local governments, as representatives of the state, (as external parties) may regulate, but these arrangements must be in the nature of respect, recognition, facilitation and strengthening. Local governments should as much as possible prevent intervention in the management of Balinese cultural tourism. For Traditional Villages with a management system, the maintenance of which is under the autonomy authority of the Traditional Village in a condition that still gives a portion to the Traditional Village.

\section{References}

[1] TRISNo Nugroho, ECONOMIC Report Of The Province Of Bali (2020).

[2] Nasir Sudirman Ramdhan, Muhammad, August Daulat, Policy Plan For Zoning Coastal Areas And Small Islands In Bali Province, 6 Minutes Agric. ENVIRON. Policy FORMUL. STRATEG. STUD. AGRIC. ENVIRONMEN 11-22 (2019).

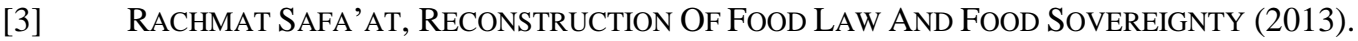

[4] Pemerintah Provinsi Bali, Peraura Daerah Provinsi Bali Nomor 16 Tahun 2009 Tentang Rencana Tata Ruang Wilayah Provinsi Bali 1 (2009).

[5] Gede Marhaendra Wija Atmaja, Politik Pluralisme Hukum: Arah Pengakuan Kesatuan Masyarakat HuKum Adat Dengan Peraturan DaERaH (2016).

[6] Gede Marhaendra Wija Atmaja, Pluralisme Konstitusional Dalam Pengakuan KESATUAN MASYARAKAT HUKUM ADAT (2016).

[7] I. W. Suweda, Sustainable, Competitive And Autonomous Urban Spatial Planning, 15 CIV. ENG. SCI. J. (2011).

[8] Mahendra Wija Atmaja, Konstitusinalitas Desa Adat: Memahami Norma Hukum Desa Adat Dalam Undang-Undang Dasar Negara Republik Indonesia Tahun 1945, "Makalah”, Seminar Nasional “ Kedudukan Desa Adat Dalam Sistem Ketatanegaraan Republik Indonesia,” JUBILIUM EMAS FAKULTAS HUKUM UnIVERSITAS UdAYANA, DiselENGGaRAKAN OleH IKATAN ALUMNI UNIVERSITAS UDAYANA (IKAYANA) KOMISARIAT FAKULTAS HUKUM UNIVERSITAS UdAYANA BEKERJASAMA DENGAN PUSAT HuKUM DAN IdIOLOGI (PKHI) DAN PEMERINTAH PROVINSI BALI, 2014.

[9] Negara RePUbliK IndONESIA, Undang-Undang Nomor 23 Tahun 2014 Tentang Pemerintahan Daerah Pasal 9 Ayat (3), (2014). 
[10] W. Peters, J.H, Wardana, Tri Hita Karana (2013). 